\title{
STUDY AND EVALUATION OF PHYSICAL ACTIVITY OF YOUTH FROM THE VISEGRAD COUNTRIES IN RELATION TO THE WHO RECOMMENDATIONS
}

\author{
Ewelina Niźnikowska ${ }^{1}$ Józef Bergierl, Barbara Bergier ${ }^{1}$, Michat Bergierl, \\ Pongrăc $\breve{A c s}{ }^{2}$, Jăn Junger ${ }^{3}$ \\ ${ }^{1}$ Department of Physical Culture and Physiotherapy, Faculty of Health and Social Sciences, \\ Pope John Paul II State School of Higher Education in Biała Podlaska, Poland \\ ${ }^{2}$ Faculty of Health Sciences, University of Pecs, Hungary \\ ${ }^{3}$ Department of Physical Education, Pavol Jozef Safarik University in Kosice, Slovakia
}

\begin{abstract}
Background. In recent years, the subject literature has provided concrete recommendations concerning health with regard to specific parameters. Therefore, it is necessary to indicate appropriate physical activity standards for proper development at various stages of human ontogenesis.

Objective. The aim of the work was knowledge of the level of physical activity of high school youth in the Visegrad countries, including gender indications, to demonstrate whether the WHO recommendations are fulfilled.

Material and methods. The research was conducted in students from four Visegrad countries: the Czech Republic, Poland, Slovakia and Hungary. As the research method, the International Physical Activity Questionnaire - IPAQ in the extended version was used.

Results. Boys seem to do much better and have largely fulfilled the WHO recommendation for high-intensity efforts performed 3 times for 20 minutes, and medium and high efforts -7 times for 60 minutes, which is particularly crucial for the effectiveness of the level of physical activity.

Conclusions. It is indispensable to continue monitoring the physical activity of young people using modern research techniques. It seems intentional to intensify promotion and educational activities, which should be aimed at motivating young people to undertake physical activity in accordance with world-wide recommendations.
\end{abstract}

Key words: physical activity, IPAQ, youth, Visegrad countries

\section{STRESZCZENIE}

Wprowadzenie. Literatura zagadnienia dostarcza na przestrzeni ostatnich lat konkretne rekomendacje z uwzględnieniem wskazanych parametrów. Potrzebne jest zatem wskazanie odpowiednich norm aktywności fizycznej dla prawidłowego rozwoju na różnych etapach ontogenezy człowieka.

Cel. Celem pracy było poznanie poziomu aktywności fizycznej młodzieży szkolnej z państw wyszehradzkich, z uwzględnieniem płci i wykazanie wypełnienia rekomendacji WHO.

Materiał i metody. Badania przeprowadzono wśród uczniów z czterech państw wyszehradzkich: Czechy, Polska, Słowacja, Węgry. Jako metodę badań wykorzystano Międzynarodowy Kwestionariusz Aktywności Fizycznej - IPAQ w wersji długiej. Wyniki. Obraz aktywności fizycznej jawi się korzystniej u chłopców, którzy w dużym stopniu wypełnili rekomendację WHO dla wysiłków o intensywności wysokiej 3 razy po 20 min. oraz średniej i wysokiej 7 razy po 60 min., co ma szczególne znaczenie dla efektywności poziomu aktywności fizycznej.

Wnioski. Nieodzownym jest dalsze monitorowanie aktywności fizycznej młodzieży z wykorzystaniem nowoczesnych technik badawczych. Za celowe wydaje się zintensyfikowanie działań promujących i edukacyjnych, których zadaniem powinno być motywowanie młodzieży do podejmowania aktywności fizycznej zgodnie ze światowymi rekomendacjami.

Słowa kluczowe: aktywność fizyczna, IPAQ, młodzież, państwa wyszehradzkie

Corresponding author: Ewelina Niźnikowska, Pope John Paul II State School of Higher Education in Biała Podlaska, Sidorska 95/97, 21-500 Biała Podlaska, Poland, phone: +48 8334469 12, e-mail: e.niznikowska@dydaktyka.pswbp.pl

(C) Copyright by the National Institute of Public Health - National Institute of Hygiene 


\section{INTRODUCTION}

The effects of civilizational change increasingly lead to a sedentary lifestyle in which people do not see the necessity of maintaining health through physical activity. It should be remembered though that physical activity is measured by such parameters as duration (volume) and its type, frequency and intensity. Physical effort will be effective only if it is taken as often and with as much intensity as possible and for a sufficiently long time.

It is assumed that a serious change concerning the role of physical activity took place when it started to be regarded as a crucial element of a healthy lifestyle $[20,26]$. In the last years, the subject literature has provided numerous requirements and recommendations with regard to concrete parameters. It has, therefore, become necessary to indicate appropriate physical activity standards for proper development at various stages of human ontogenesis. And so, Strong et al. [22] indicate, the US youth should spend no longer than 60 minutes for medium and high intensity daily. There is also a regular recommendation on an amount of exercise by an American College of Sport Medicine [1], which proposes moderate intensity effort at least 30 minutes daily, not less than 5 times a week, or high-intensity effort at least 20 minutes daily three times a week. In turn, the European Union [8] forwards the following three standards of physical activity to comply with: a) 20 minutes of high intensity effort 3 times a week, b) 30 minutes of medium intensity five times a week, c) 30 minutes of low intensity (walking) five times a week. In addition, the Healthy People 2020 program [24], beside the requirements for appropriate physical activity, points to the need of reducing the amount of the time spent on watching TV to two hours a day.

Furthermore, the recommendations of reducing work have been supplemented with a variant of getting involved in medium and high intensity-effort 7 times a week for 60 minutes. As a criterion of a healthy lifestyle, the number of steps performed daily is also given, which is 11,000 for adolescents [23], with 9,000 steps for girls and 11,000 for boys [9]. On the other hand, among the undesirable changes in the lifestyle of school youth, an increase in the time spent sitting has been indicated [6, 14, 21]. An all-too-common sedentary lifestyle leads to overweight and obesity. Therefore, the aim of the study was knowledge of the level of physical activity of high school youth in the Visegrad countries, including gender considerations, to demonstrate whether the young people comply with the WHO recommendations.

\section{MATERIAL AND METHODS}

The research on lower and upper secondary school students aged 15 to 17 four Visegrad countries: the Czech Republic, Poland, Slovakia and Hungary was conducted in April 2015. Overall, were examined 2425, out of which 499 (20.6\%) were eliminated, due to their incompleteness. As the research method, the International Physical Activity Questionnaire - IPAQ in the extended version was used in on-line INDARES system. The number of respondents considering gender and age is presented in Table 1.

Table 1. Characteristics of the respondents by gender and age

\begin{tabular}{|l|c|c|}
\hline \multicolumn{1}{|c|}{ Age (in years) } & Boys (\%) & Girls (\%) \\
\hline 15 & $191(23.7)$ & $280(25.0)$ \\
16 & $249(31.0)$ & $341(30.4)$ \\
17 & $365(45.3)$ & $500(44.6)$ \\
\hline Total & $\mathbf{8 0 5}(\mathbf{4 1 . 8})$ & $\mathbf{1 1 2 1}(\mathbf{5 8 . 2})$ \\
\hline
\end{tabular}

The extended version of IPAQ consists of five parts containing 27 questions in such domains as work/study, transportation, housework, recreation and sport, and time spent sitting. Each type of physical activity was expressed in three energy dimensions: vigorous, moderate, walking. The total physical activity was calculated by estimating the data in MET-min./times in particular domains, multiplying the duration in minutes by the number of days and the corresponding intensity factor: walking 3.3 , moderate -4.0 , vigorous - 8.0. At the same time, 1 MET corresponds to the consumption of oxygen at rest and amounts to $3.5 \mathrm{ml} 02 / \mathrm{kg}$ of body weight per minute.

The statistical analysis was performed in the STATISTICA programme v. 10. The level of physical activity was presented in the form of arithmetic means and standard deviations. To detect statistically significant differences between boys and girls, the Mann-Whitney $\mathrm{U}$ test was applied. If they belonged to a given recommendation groups, the data were presented in percentages and the Pearson Chi-square test was used. In all analyzed cases, the significance level was assumed at $\mathrm{p}=0.05$.

\section{RESULTS}

\section{The level of physical activity of students by gender}

The level of weekly total physical activity in boys was 7.291 MET and was substantially higher than in girls 6,200 MET. Significantly higher physical activity in boys was also demonstrated in the sports activity domain, i.e. 2,471 MET, with 1.951 MET in girls. No significant variation was detected in other domains: school-, transportation- and home-related activity (Figure 1). 


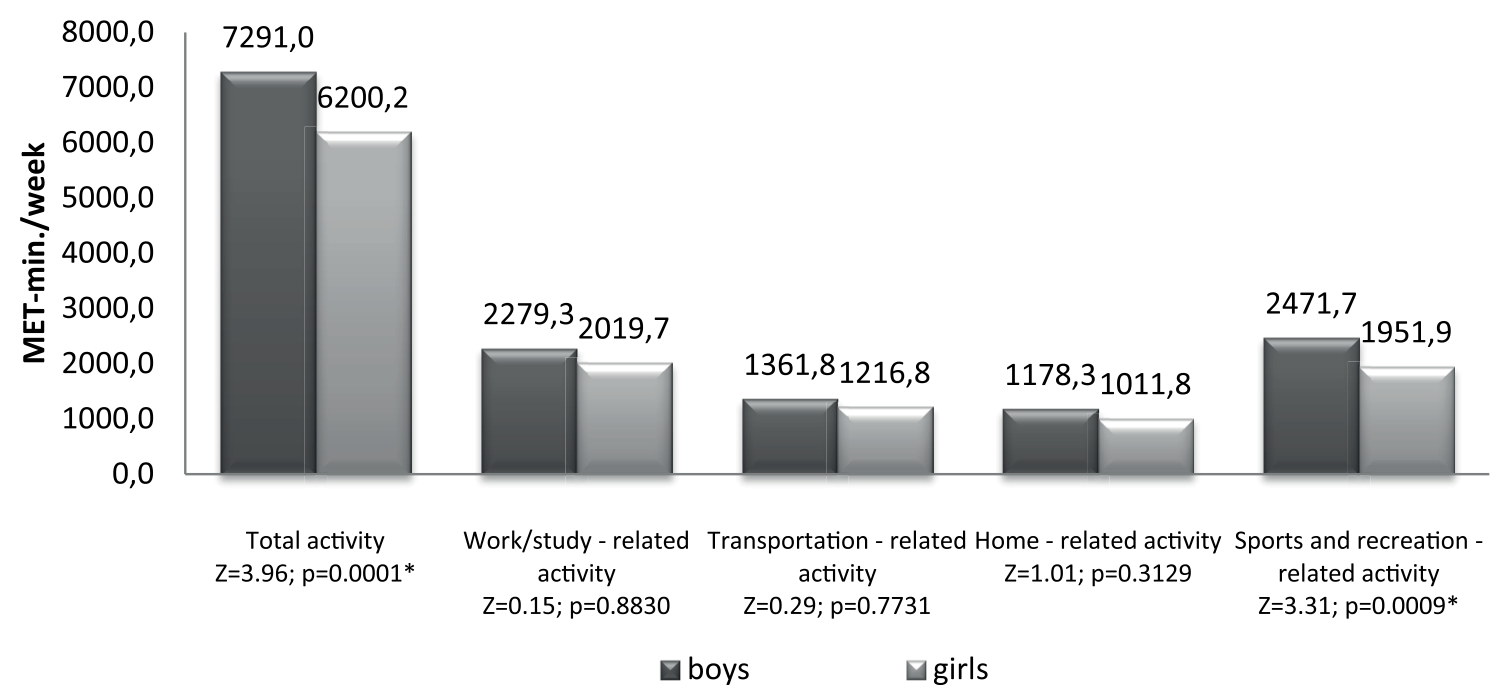

* - significant variation at $\mathrm{p}<0.05$; Z-value of the Mann-Whitney $\mathrm{U}$ test

Figure 1 . The level of total physical activity and its areas (domains) by gender

A detailed analysis of the time data of physical activity (in minutes) within particular domains and the intensity of efforts showed a large variation between in girls and boys. The boys devote significantly more time to vigorous efforts in the domain of home-related activity, i.e. 44.7 minutes vs. - 29.4 minutes in girls $(\mathrm{p}=0.0000)$ and sports and recreation-related activity, with 51.5 minutes and 40.2 minutes $(P=0.0000)$ respectively. However, there was no significant difference in the domain of school activity. The boys are also significantly more active in the domain of transportation, doing cycling - 33.9 minutes and 22.4 minutes respectively $(\mathrm{p}=0.0000)$, while girls in walking, 48.1 minutes and 41.2 minutes respectively, i.e. an effort of relatively low intensity (Table 2).

An unfavourable phenomenon visible in girls, less so in boys, is a significantly low amount of free time spent sitting in the means of transport, 70.9 minutes and 63.6 minutes respectively $(\mathrm{p}=0.0004)$ and in other places on working days, 432.1 minutes and 392.7 minutes respectively $(\mathrm{p}=0.0000)$ (Table 2$)$.

Table 2. Weekly quantitative dimension of physical activity in particular domains by gender (in minutes)

\begin{tabular}{|c|c|c|c|c|c|c|c|}
\hline \multirow{2}{*}{ No. } & \multirow{2}{*}{ Domain } & \multicolumn{2}{|c|}{ Girls } & \multicolumn{2}{|c|}{ Boys } & \multicolumn{2}{|c|}{ Test } \\
\hline & & mean & SD & mean & SD & $\mathrm{z}$ & $\mathrm{p}$ \\
\hline \multirow{4}{*}{1.} & \multicolumn{7}{|c|}{ School-related activity } \\
\hline & Vigorous & 38.6 & 56.1 & 43.6 & 61.2 & -1.16 & 0.2453 \\
\hline & Moderate & 34.5 & 51.8 & 40.3 & 55.6 & -1.70 & 0.0892 \\
\hline & Walking & 46.0 & 59.4 & 41.7 & 58.1 & 2.08 & $0.0375^{*}$ \\
\hline \multirow{3}{*}{2.} & \multicolumn{7}{|c|}{ Transportation-related activity } \\
\hline & Cycling & 22.4 & 44.5 & 33.9 & 53.8 & -6.06 & $0.0000^{*}$ \\
\hline & Walking & 48.1 & 56.4 & 41.2 & 55.9 & 49.3 & $0.0000^{*}$ \\
\hline \multirow{4}{*}{3.} & \multicolumn{7}{|c|}{ Home-related activity } \\
\hline & Vigorous around home & 29.4 & 51.5 & 44.7 & 61.2 & -6.83 & $0.0000^{*}$ \\
\hline & Moderate around home & 39.8 & 51.3 & 41.7 & 54.3 & 0.10 & 0.9226 \\
\hline & Moderate at home & 47.7 & 50.6 & 35.1 & 47.7 & 7.68 & $0.0000^{*}$ \\
\hline \multirow{4}{*}{4.} & \multicolumn{7}{|c|}{ Sport and recreation-related activity } \\
\hline & Vigorous & 40.2 & 50.7 & 51.5 & 56.8 & -4.63 & $0.0000^{*}$ \\
\hline & Moderate & 28.8 & 45.7 & 37.0 & 51.4 & -4.03 & $0.0001 *$ \\
\hline & Walking & 52.8 & 55.3 & 49.1 & 55.5 & 2.57 & $0.0102 *$ \\
\hline \multirow{4}{*}{5.} & \multicolumn{7}{|c|}{ Sitting } \\
\hline & a) In means of transport & 70.9 & 57.7 & 63.6 & 55.7 & 3.51 & $0.0004 *$ \\
\hline & $\begin{array}{l}\text { In public places on working } \\
\text { days }\end{array}$ & 432.1 & 200.9 & 392.7 & 237.3 & 4.89 & $0.0000^{*}$ \\
\hline & During the weekend & 296.6 & 198.5 & 312.9 & 231.6 & -0.57 & 0.5707 \\
\hline
\end{tabular}

* - significant variation at $\mathrm{p}<0.05 ; \mathrm{Z}$-value of the Mann-Whitney $\mathrm{U}$ test 
The majority of boys undertake efforts of high intensity and perform them 3 times a week for 20 minutes $(48.6 \%)$ and of medium and high intensity 7 times for 60 minutes (38.8\%). In contrast, girls do that mainly with regard to high intensity efforts three times a week for 20 minutes (37.4\%) and to high and medium efforts 7 times a week for 60 minutes (33.4\%). Significant differences in the percentage of persons representing groups with recommended levels of physical activity were shown in relation to all groups except for WPA $5 \times 30$ (Figure 2).

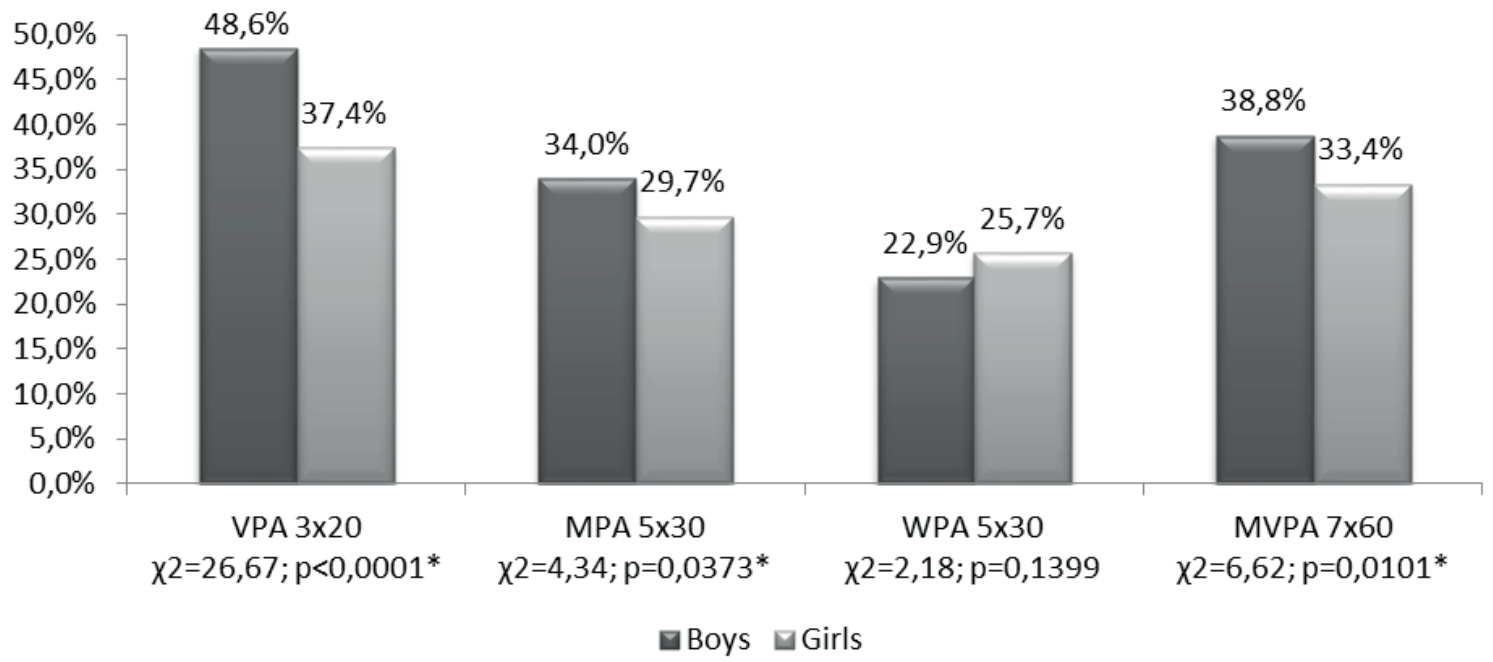

VPA 3×20 - High-intensity AP performed 3 x 20 minutes a week

MPA $5 \times 30$ - Medium-intensity AP performed $5 \times 30$ minutes per week

LPA $5 \times 30$ - Low-intensity AP performed 5 × 30 minutes a week

MVPA 7x60 - Moderate and vigorous intensity AP completed 7 x 60 minutes a week

* -a significant differentiation at $\mathrm{p}<0.05 ; \chi 2$-value of Pearson's Chi-square test

Figure 2. WHO recommendations of physical activity with gender mainstreaming

\section{Recommendations of physical activity with regard to gender}

The level of weekly physical activity shows statistically significant differences with varying intensity of efforts in boys and girls. These differences concern high-intensity efforts undertaken 3 times a day for 20 minutes each week (VPA 3x20), with a moderate intensity -5 times a week for 30 minutes (MPA 5x30) and moderate and high intensity -7 times a week for 60 minutes (MVPA 7x60). On the other hand, there were no significant differences within the particular gender at low-intensity efforts undertaken 5 times a week for 30 minutes (LPA 5x30) (Figure 2).

\section{DISCUSSION}

It is almost universally believed that proper physical activity is crucial for health maintenance in contemporary generations. Research conducted in high school students from different countries shows their insufficient activity $[5,7,10,11,18,25]$.

The essence of the International Physical Activity Questionnaire-IPAQ [4] is the possibility of comparing the results among respondents from different states. The obtained values of the total weekly PA of the youth of the Visegrad countries (Czech Republic,
Poland, Slovakia, Hungary) at the level of 7,291 MET in boys and 6,200 MET in girls is much higher than the ones found in the youth surveyed by the same questionnaire in Lithuania [2], Czech Republic [13] or Croatia [12]. Similar high values as the ones obtained in the respondents from the Visegrad countries were demonstrated only in young people from Spain [5], which allows for assessing the level of total weekly physical activity both in the boys and in girls as good.

The findings in the study on physical activity in high school youth obtained with the extended version of IPAQ show higher values in boys than in girls in Latvia [2], 4,895 MET and 4.404 MET respectively, and in the Czech Republic [13] - 5,220 MET and 2,372 MET. The same pattern is visible in the studies on the Spanish youth [5], though they were calculated on one day, not a week. The values in boys amounted to 855 MET, and 656 MET in girls.

Own research confirms that it has become almost a norm that boys demonstrate higher physical activity in each of four countries: the Czech Republic, Poland, Slovakia and Hungary and the values in individual countries range from 4.546 MET to 10,280 MET in boys, and from 4.079 MET to 7.287 MET in girls.

The research in other studies has also confirmed much regularity in the higher level of physical activity 
demonstrated in boys $[4,5,13,15,16,17,19]$, which is mainly explained by less interest in motor activities in girls at this age. There might be another reason that could explain the results - the offer of physical activities for girls and the way they are run is not very attractive.

Still, it is particularly essential to follow the WHO recommendations on physical activity for the youth of the Visegrad countries. As indicated, this image appears to be more beneficial for boys who have largely fulfilled the recommendations for highintensity efforts 3 times 20 minutes and medium and high-intensity efforts -7 times for 60 minutes, which is particularly crucial for the effectiveness of the overall level of physical activity.

\section{CONCLUSION}

It is indispensable to continue monitoring the physical activity of young people using modern research techniques. It seems intentional to intensify promotion and educational activities, which should be aimed at motivating young people to undertake physical activity in accordance with world-wide recommendations.

\section{Conflict of interset}

The authors declare no conflicts of interest.

\section{Acknowledgements}

The authors express their thanks to Ferdinand Salonna, PhD from Palacky University Olomouc, the Czech Republic for the consultation during the research and Adam Szepeluk M.Sc. from the Innovation Research Centre, Pope John Paul II State School of Higher Education in Biala Podlaska, Poland, for the assistance in statistical analysis.

\section{REFERENCES}

1. American College of Sports Medicine. ACSM's Resource Manual for Guidelines for Exercise Testing and Prescription. 6th edition. American College of Sports Medicine. 2010.

2. Bergier B., Bergier J., Wojtyła A.: Various aspects of physical activity among Lithuanian adolescents. Ann Agric Environ Med, 2012;19(4):775-779.

3. Biernat E., Piatkowska M.: Recommendations of the World Health Organization on leisure physical activity and their implementation among Polish population. Polish J Sport Med, 2013;4(4):255-264.

4. Booth M.L.: Assessment of Physical Activity: An International Perspective. Res Q Exerc Sport, 2000;71:114120.

5. Cocca A., Liukkonen J., Mayorga-Vega D., Viciana-Ramirez J.: Health-related physical activity levels in Spanish youth and young adults. Percept Mot
Skills: Physical Development \& Measurement, 2014;118(1):247-260.

6. Crombie A.P., Illich J.Z., Dutton G.R., Panton L.B., Abood D.A.: The freshman weight gain phenomenon revisited. Nutr Rev, 2009;67(2):83-94.

7. Dmitruk A., Kunicka I., Popławska H., Holub W.: Relationship between diet and physical activity level in adolescents from post-grammar schools. Rocz Panstw Zakl Hig, 2016;67(1):37-44.

8. EU Physical Activity Guidelines, Recommended Policy Actions in Support of Health-Enhancing Physical Activity. Available http://ec.europa.eu/assets/eac/sport/ library/policy_documents/eu-physical-activity-guidelines-2008 en.pdf(Accessed 13.07.2018)

9. Frömel K., NovosadJ., Svozil Z., Sigmund E., Vašendová J., Formánková S., Klimotová H., Dopitová R.: School youth physical activity. In: Válková H., Hanelová Z. eds. Movement and Health. Univerzita Palackeho. Olomouc, 1999;29-33.

10. Groffik D.: Struktura aktywności fizycznej młodzieży 15-17 letniej Górnego Śląska [Structure of physical activity in the 15-17 year olds in Upper Silesia]. AWF, Katowice, 2015 (in Polish).

11. Janssen I., LeBlanc A.G.: Systematic review of the health benefits of physical activity and fitness in school-aged children and youth. Int J Behav Nutr Phys Act, 2010;7:40.

12. Jurakić D., Pedisić Ž., Andrijasević M.: Physical Activity of Croatian Population: Cross-sectional Study Using International Physical Activity Questionnaire. Croat Med J, 2009;50:165-73.

13. Kudlacek M.: Increase of the effectiveness of school PE classes through sport preferences survey: Contextual prediction of demanded sport activities. Acta Univ. Palacki. Olomuc., Gymn., 2013;43(1):42-48.

14. Pate R.R., Mitchell J.A., Byun W., Dowda M.: Sedentary behaviour in youth. Br J Sports Med, 2011;45:906-913.

15. Paudel S., Subedi N., Bhandari R., Bastola R., Niroula $R$., Poudyal A.K.: Estimation of leisure time physical activity and sedentary behaviour among school adolescents in Nepal. BMC Public Health, 2014;14:637.

16. Pelegrini A., Silva D.A, Claumann G.S, Cardoso T.E, Ferreira de Lima e Silva J.M, Petroski E.L.: Practice of walking, moderate and vigorous physical activity and associated factors in adolescents from a state capital of southern Brazil. Rev Bras Cineantropom Desempenho Hum, 2015;17(1):11-20.

17. Popovych D., Bergier J., Korda M., Klishch I., Sopel O., Tsybulskaya I.: Evaluation of physical activity, body mass index and self-assessment of physical fitness in female students and pupils of Ternopil, western Ukraine. Health Prob Civil, 2017;11(3):163-172.

18. Raglin J.S., Wilson G.S., Galper D.: Exercise and its effects on mental health. In: Bouchard C., Blair S.N., Haskell W.L. eds. Physical Activity and Health. Leeds, Human Kinetics, 2007;247-259.

19. Rangul V., Holmen T.L, Kurtze N., Cuypers K., Midthjell $K .:$ Reliability and validity of two frequently used selfadministered physical activity questionnaires in adolescents. BMC Med Res Meth, 2008;8:47-57. 
20. Sallis J.F., Owen N.: Physical activity and behavioral medicine. Thousand Oaks: Sage Publications, 1999.

21. Sigmundova D., Chmielnik K., Sigmund E., Feltlova D., Frömel K.: Physical activity in the lifestyle of Czech University students: Meeting health recommendations. Eur J Sport Sci, 2013;13(6):744-750.

22. Strong W.B., Malina R.M., Blimkie C.J., Daniels S.R., Dishman R.K., Gutin B., Hergenroeder A.C., Must A., Nixon P.A., Pivarnik J.M., Rowland T., Trost S., Trudeau $F$ : Evidence based physical activity for school-age youth. J Pediatr, 2005;146(6):732-7.

23. Tudor-Locke C., Bassett D.R.: How many steps/day are enough? Preliminary pedometer indices for public health. Sports Med, 2004a;34:1-8.
24. U.S. Department of Health and Human Services Strategic Plan - FY 2007-2012. Available https://aspe.hhs. gov/us-department-health-and-human-services-strategic-plan-fy-2007-2012 (Accessed 03.09.2018)

25. Wasilewska M.: In search of the assessment of the physical activity level of the youth with the use of the IPAQ. Health Prob Civil, 2017;11(1):15-22.

26. Zapolska J., Witczak-Sawczuk K., Krawczuk-Rybak M., Sawicka-Żukowska M., Smarkusz J., Ostrowska L.. Comparison of diet and physical activity of children and adolescents with patients after cancer treatment. Rocz Panstw Zakl Hig, 2018;69(1):79-86.

Received: 21.02.2019

Accepted: 01.04.2019 